\title{
Academic Librarians and the
}

\section{Library and Information Science Monograph: An Exploratory Study} Peter Hernon

\begin{abstract}
The present climate of economic retrenchment and information sharing has direct implications for the purchase of library and information science monographs by academic libraries. This paper explores the collection and use of these monographs by academic librarians. Furthermore, the paper shows the preferences of academic librarians for literature that has practical applications. The exploratory research also indicates possible topics meriting further investigation.
\end{abstract}

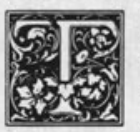

he hard sciences value publication primarily in the form of scholarly journal articles. Such articles constitute a means by which scientists in academe achieve the recognition of their peers, promotion, tenure, and, in some instances, financial reward. Charles B. Osburn reminds us that

publication is not a peripheral function of research; it is rather an integral part of the scholarly process that would be rendered incomplete and valueless without it. By proportion, the journal is the most characteristic expression of the spirit of science and scholarship, and its history embraces the contribution of science and scholarly research. ${ }^{1}$ As university libraries and schools of library and information science (LIS) adopt the scientific model, the article, presumably in refereed journals, becomes the primary publication vehicle for disseminating the results of research in LIS and for bestowing academic recognition on the authors. ${ }^{2}$

Various writers have asserted the importance of scholarly journal articles in LIS. ${ }^{3}$ Diane Mittermeyer, Lloyd J. Houser, and Wilma Sweaney, however, assert that the literature of library administration does not follow the scientific model. ${ }^{4}$ Rather, that literature exhibits a preference for monographs over journals. ${ }^{5}$ These findings, according to the researchers, indicate that the literature used is not scholarly, draws on a knowledge base older than the normal social sciences, and reflects "an affinity with a humanities style of literature production rather than a scientific one." ${ }^{16}$ Furthermore, they suggest that library administration depends on areas other than LIS for its theoretical material.

Sharon J. Rogers and Charlene S. Hurt maintain that the scholarly journal will become obsolete as the primary vehicle for scholarly communication. They foresee its replacement by electronic networks. ${ }^{7}$ The apparent preeminence of scholarly journals and perhaps, by extension, electronic networks calls into question the role and importance of other forms for conveying the written results of research and scholarship-for example, dissertations and monographs in LIS.

Calvin J. Boyer discusses the doctoral dissertation, but not as part of the scien-

Peter Hernon is Professor at the Graduate School of Library and Information Science, Simmons College, Boston, Massachusetts 02115. 
tific information flow in LIS. ${ }^{8}$ Beverly P. Lynch notes that librarians seldom refer to dissertations and formal research reports. ${ }^{9}$ No study reported in the literature has explored the collection and use of LIS monographs by academic librarians. Such research ultimately will place the monograph in proper perspective: the uses of the literature and preferences of academic librarians in scholarly communication. The resulting insights might be useful to publishers of LIS monographs and to authors writing (or planning to write) such works, as well as to those responsible for collection development. The research also might remind academic librarians about the presence of the monographic literature and disclose topics appropriate for national discussion and debate.

The declining sales potential for many monographs affects authors and serves as a reminder that narrowly conceived books will have limited impact.

Librarians express dismay over the rising cost of serials, particularly foreign and scientific journals, and monographs. "Much is made of the specter of journals consuming the entire materials budget of a library." 10 To avoid this possibility, Robin B. Devin and Martha Kellogg, as well as others, have offered guidelines for coping with the serials explosion and balancing resource allocations to serial and monograph collections. " However, none of these studies has sufficiently examined collections of LIS monographs housed in academic libraries. Important questions include:

- How much of the materials budget do academic libraries allocate to the purchase of LIS monographs?

- At institutions that do not have LIS programs, how many LIS monographs do the libraries purchase from their general fund?

- Do the libraries have standing orders with LIS publishers such as the American Library Association (ALA)?
- Who reads LIS monographs and why? The answers to such questions provide insights into the extent to which academic librarians purchase and use the literature of their own profession and discipline.

Apparently, the sales market for many LIS monographs has declined in recent years, although the number of monographs produced annually is sizable..$^{12}$ In past years, a title might have sold 1,500 or more copies; today, many publishers find that a majority of their titles sell fewer than 800 copies. $^{13,14}$ In fact, some publishers are reducing the number of LIS monographs they produce. Contrary to the expectations of some authors and publishing houses, recent events in Eastern Europe and the Soviet Union have not created opportunities for publishers to sell books in these countries. Instead, the governments must use their scarce resources to combat inflation, restructure their economies, and provide people with basic necessities. Conceivably, the governments may have to sell some art treasures to raise the necessary finances to avoid further recession. ${ }^{15}$ Neither the People's Republic of China, India, nor Latin and South America have purchased numerous copies of LIS monographs. ${ }^{16}$ In fact, some jobbers in certain Third World countries apparently have been unreliable in paying certain publishing houses for the titles they have distributed within the countries. ${ }^{17}$

The declining sales potential for many monographs affects authors and serves as a reminder that narrowly conceived books will have limited impact. Expressed another way, the LIS monograph will probably undergo transformation and become more responsive to market preferences. After all, few authors want to spend enormous amounts of time producing monographs that do not sell well. Some authors, however, might make the sacrifice once because they suspect that having written a monograph might be advantageous, assisting them in getting a particular job, a promotion, or tenure or earning them acclaim. ${ }^{18}$

In summary, an assessment of the LIS monograph is long overdue. This paper 
makes a modest beginning and encourages others to build from its preliminary research base. For the purposes of this study, the term "monograph" includes titles emanating from scholarly publishers: commercial houses, professional associations, and university presses. ${ }^{19}$ These titles may convey research findings. Textbooks that identify research and summarize the results of various studies fit within the scope of a monograph. Reference works have been excluded in the belief that they merit separate analysis.

\section{OBJECTIVES}

The study objectives were to:

- Determine the role and perceived importance of the LIS monograph to academic library collection development. Importance is defined as the extent to which libraries purchase these monographs;

- Describe the perceptions of a sample of academic librarians regarding their use and nonuse of LIS monographs;

- Identify issues affecting the use and nonuse of LIS monographs; and

- Identify areas meriting further research.

The author hopes that the results of the study will direct national and international discussion to the role and relative importance of the monograph to scholarly communication in LIS. Furthermore, this article may serve as a reminder to authors seeking journal publication that their literature review should include all significant works, including those published as monographs.

\section{STUDY DESIGN AND METHODOLOGY}

Given the exploratory nature of the study, the lack of existing research on the perceptions of librarians toward the monographs of their profession and discipline, and the need to obtain in-depth data to identify areas meriting further investigation, this researcher conducted a series of focus group and individual interviews during the spring, summer, and fall of $1990 .{ }^{20}$ Group interviews took place with librarians at three academic institutions that were members of the
Association of Research Libraries (ARL). Located in the Midwest, South, and Southwest, the libraries selected were:

- Geographically accessible to the investigator; and

- Willing to participate in the study. Willingness was defined as allowing five or more librarians to participate in focus group interviews.

Two of the universities had graduate schools of LIS accredited by ALA. One university was selected because it did not have such a school. However, there are two such schools in the state.

Focus group participants included administrators, selectors for the LIS collection in the university library, librarians who have conducted research and been published, and those aspiring to write. To guide the discussion, the investigator relied on a basic set of interview questions that probed the perceived importance of monographs in comparison to journal articles; librarian use of monographs; how the librarians discovered titles; what types of monographs they consulted; whether they purchased personal copies of monographs or preferred to order titles for the libraries' collections; and whether they borrowed monographs from other institutions. The investigator also shared the insights gained from previous interviews so that the interviews built on each other and were comparative.

In addition to the group interviews, the investigator conducted seven individual interviews with library school librarians and academic librarians at both ARL and non-ARL institutions. The nonARL institutions offered doctoral degrees, and the librarians held faculty status requiring publication. Publication, however, was not limited to the conduct and reporting of research. The purpose of the individual interviews was to obtain additional insights into the role of the LIS monograph and to ascertain the extent to which academic libraries have requested LIS monographs through interlibrary loan. The investigator also had the option of comparing the views of librarians participating in group interviews to this different sample of academic librarians. 
A total of forty-five academic librarians participated in the focus group and individual interviews. These interviews were conducted within a case study context and produced qualitative, not quantitative, data. ${ }^{21}$ Case studies are useful both for exploratory research and for descriptive and explanatory purposes. Such a design is especially relevant for studying knowledge utilization because the topic covers a phenomenon inseparable from its context. ${ }^{22}$ Furthermore, case studies focus on a specific target group and attempt to describe the subject's behaviors and the relationship of these behaviors to selected environmental variables or conditions. Such studies allow investigators to probe in depth, identify variables and propositions that can serve to direct additional research, and "develop insight into basic aspects of human behavior... [and] may lead to the discovery of previously unsuspected relationships." 23

The investigator assured participants that their comments would be kept confidential and not attributable to either a particular institution or a particular individual. Group interview sessions generally lasted one and one-half hours, while individual interviews lasted between thirty minutes and one hour. During an interview session, the investigator took brief notes summarizing the discussion. Later the same day, he reviewed the notes, expanding on the points made by participants. The notes from the group and individual interviews were analyzed together, with the results reported in this paper.

\section{QUALITY OF THE DATA}

To increase the reliability of the data, the investigator conducted two pretests with doctoral students at two LIS graduate schools. The students selected had all worked as academic librarians. The library science librarian at one of these schools also participated in the interview. The purpose of the pretests was to preview the procedures for conducting the focus group interviews and to identify appropriate questions. The investigator added some questions based on the responses of the pretest participants.
Furthermore, he recorded the responses of the participants during the interview and then produced a detailed summary immediately after the completion of the interview. The same interview questions guided both the focus group interviews and the individual interviews, and there was a significant degree of similarity in the responses of the participants.

Internal validity assesses the extent to which data collection procedures actually measure what the investigator intends them to measure. The investigator, together with those interviewed, suggested examples of LIS monographs. Interviewees were encouraged to identify one title that they had recently read or planned to read in the next month. Interestingly, they most frequently mentioned Patricia S. Breivik and E. Gordon Gee's Information Literacy, F. W. Lancaster's If You Want to Evaluate Your Library, or Nancy A. Van House et al.'s Measuring Academic Library Performance. ${ }^{24}$ The internal validity of the data was enhanced by matching questions within and across the group interviews and individual interviews and by obtaining the opinion of practicing academic librarians as to whether the questions and definitions accurately represented the variables under study, that is, face validity.

In an exploratory study such as this, greater attention is placed on reliability and internal validity than on external validity, or the generalizability of study findings to a larger population (e.g., type of academic library, a geographical region, and all academic libraries in the United States). Thus, the investigator sacrificed generalizability of study findings to increase the study's reliability and internal validity, to identify propositions meriting further research, to probe specific areas under investigation, and to obtain detailed insights into the phenomenon under investigation. There was insufficient financial support to place external validity on par with reliability and internal validity considerations.

\section{FINDINGS}

Practicing librarians consulting the published literature rely on articles, ${ }^{25}$ primar- 
ily from the more widely circulating journals ${ }^{26}$-those routed to them or received as part of professional association membership. Articles convey more timely information than do monographs. Many of the librarians interviewed used the literature to identify individuals working on similar problems or tasks, and thereby attempt to expand their interpersonal networking. They regard monographs as secondary resources, ones not always essential to their collection development and management practices. Furthermore, they believe that most research appears in journals and that monographs take too long to read. If the author of a monograph has had a chapter of his or her work published as an article, those interviewed are often satisfied with the reading of the summary article. They neither request the purchase of the monograph nor read it.

Although the following findings underscore the size of a library's budget and the perceived utility of monographs, other factors influence selection. One of these factors is the anticipated amount of potential use. Institutions that do not offer LIS programs may be hard pressed to justify the purchase of monographs that have limited appeal. ${ }^{27}$ An LIS monograph might interest only a couple of staff members. Another key issue relates to what the library should own or have nearby and what staff are willing to wait for on interlibrary loan. Either through planning or by default, many librarians interviewed place most LIS monographs under the province of interlibrary loan. Some of them were considering borrowing and examining selected works for possible purchase by the library.

\section{Quality of LIS Literature and the Specialization of the Literature}

Charles R. McClure and Ann Bishop, who interviewed nationally known researchers, discovered a belief that the quality of LIS research was improving. ${ }^{28}$ Although the study reported in this article did not focus exclusively on research, it did probe librarian perceptions of the published literature: The librarians interviewed question the quality of much of the literature and do not consider its quality to be improving. ${ }^{29}$ The critical issue for them becomes how to separate the quality works from the quantity that is published annually.

The academic librarians pointed out that library literature has become more specialized and that it does not adequately cover major developments relating to transborder data flow and other aspects of information policy. A study such as the one presented in this paper deals with the use of only one type of published literature. At the same time, the LIS literature is a subset of the social sciences literature. One librarian interviewed explained that "we need to justify our literature better within the broader context so that our literature has a wider appeal."

\section{Collection Development}

One of the universities with a graduate school of LIS had had a separate LIS collection since the 1970s. However, the university library was in the process of dismantling the separate collection and integrating the holdings into the general collection. The position of library science librarian had been phased out, and one of the acquisitions librarians had recently taken over selection responsibilities for the LIS collection along with her other responsibilities. The librarians interviewed at this institution maintained that if the university did not have a library school, they would place more emphasis on the serials collection and deemphasize the acquisition of monographs.

At one of the pretest sites, there was a separate library science collection and librarian. This collection contained only course-related materials. A librarian within the university library was charged with selection responsibilities. However, there was no coordination between the two librarians, and the library science librarian assumed that the university library was developing a comprehensive collection of LIS titles. This librarian had not checked on the accuracy of his assumption.

The university library that did not have a graduate school of LIS presumed 
that one of the two schools in the state maintained a comprehensive collection from which the staff could borrow if the need arose. One of the librarians interviewed from a western state university library explained that her library allotted only $\$ 200$ per year for the purchase of LIS monographs. Because there was little hope that the library would purchase a requested title, she had little reason to submit book orders.

At another library, the administration handled the purchase of LIS monographs and tended to make the purchases in areas of personal interest to them. According to those interviewed, the collection was "adequate" for technical services, but "weak" in other areas.

Evidently, practices vary. It would seem, though, that libraries build more complete collections of LIS monographs when a particular person is charged with collection responsibilities, when the collection development policy covers the inclusion of LIS titles, and when a notification system alerts librarians that a requested title has arrived. As one librarian explained,

I often forget that I have requested a title. Without the notification system, the title would arrive and someone else would probably take it and keep it in his or her office. Consequently, without the system, there would be little incentive for me to place an order. Given the small budgets allocated for the purchase of LIS monographs, some librarians determine whether a title has general interest. If it does, they might order it from the general or departmental fund to avoid drawing on the LIS budget. Others interviewed either directly charge the LIS budget or do not bother placing an order for an LIS monograph. ${ }^{30}$ Clearly, there is great variation in the willingness of those interviewed to order LIS monographs for the library collection.

\section{Types of Monographs Preferred}

The librarians interviewed showed little interest in monographs that convey basic research and theory. Rather, they want how-to-do-it manuals, summaries of the published literature, and statistics and research methods books that would be helpful in conducting and reporting research. Some of the librarians are interested in the collection of reprinted articles and textbooks. Regardless, the monographs should have a practical application and not merely add to knowledge or one's understanding of librarianship. ${ }^{31}$ Furthermore, the librarians do not expect monographs to convey timely information, but they do want the monographs to provide a broad overview. After all, monographs can be an "integrating factor for our fragmented daily life."

Those interviewed regard monographs as a general synthesis of timeless, not trendy, information. When monographs become too introductory, they meet the needs of LIS students better than they do practicing academic librarians. Monographs may contain contributed essays and thereby reflect different points of view. A collection of monographs over time would reflect the thinking of the time period and show the evolution of library theory, philosophy, research, and practice. Such a collection, however, would be low priority, excepting perhaps at institutions serving LIS schools culminating in the award of a doctoral degree.

As for topics on which they might like to see new monographs, the librarians suggested research methods, networking, the pace of change, information policy, and library applications of microcomputer software. Writings on research methods should contain numerous examples and enable readers to apply the principles to their work situations. As one librarian explained, "We do not know how to do research; we've never had to do it before."

\section{Monograph Use by Library Managers}

At one ARL library, those in managerial positions are more likely than those in nonmanagerial positions to consult the monographic literature. The managers believe that the literature contains useful writings, covering topics such as personnel matters. This finding supports the research cited in endnote four. 
The librarians not holding managerial positions at this library emphasized that their jobs do not lend themselves to reflection and integration of the literature. However, now that they have faculty status and are expected to write for publication, they professed a desire to keep abreast of the published (predominantly periodical) literature in areas of immediate interest.

\section{Monograph Publishers, \\ Selection Sources, and the \\ Purchase of Monographs}

Those librarians who use monographs tend to rely on titles distributed by the major publishers in the United States. Librarians at only one interview site expressed interest in the acquisition of monographs produced in other countries: Australia, Canada, England, and New Zealand.

Selectors of LIS monographs prefer to pick and choose titles instead of having their libraries maintain standing orders for all titles coming out in a particular book series or from a particular publisher. These librarians peruse announcements in American Libraries and in newsletters, examine publishers' fliers and catalogs, and browse reviews contained primarily in periodicals routed to them or in periodicals that they receive as part of professional association membership. The periodicals that they most often consult are Library Journal and the Journal of Academic Librarianship. They also ask colleagues for recommendations.

The librarians rely on the above-mentioned mechanisms as filters for separating quality works from the quantity of published literature. They consider themselves too busy to spend great amounts of time searching for potentially useful titles. (Librarians engaged in research and publication welcome the inclusion of $\mathrm{Li}$ brary Literature on CD-ROM, but wish that all monographs would have descriptive titles reflecting their contents.)

Few of the librarians interviewed purchase personal copies of LIS monographs. They prefer to order titles for the library collection because the price for personal copies is often prohibitive. If they purchase a personal copy, that work is practical, consulted frequently, workrelated, and a bench mark in the field. Nonetheless, they still might try to have the library purchase an office copy of the work. One librarian suggested that the unwillingness to purchase personal copies might be the trait of a profession that does not pay well.

Selectors of LIS monographs prefer to pick and choose titles instead of having their libraries maintain standing orders.

The librarians interviewed do not need access to recently published monographs. Because there is little institutional money for the purchase of this type of literature, they want some assurance that a work has utility. The assumption is that the work will remain in print or that other institutions will loan their copies.

If the librarians decide that a title has utility, and assuming that they have not exceeded the small budget allocated for the purchase of LIS titles, they may request a copy. Some librarians interviewed dislike spending a large sum for a short book-fewer than 200 pages. For them, cost is a key factor; after all, as one librarian declared, "I do not want to waste scarce library money." ${ }^{\prime 32}$

\section{Reasons for Using LIS Monographs}

Monographs provide background information and an overview of a topic or an area and show what has been done in the past. They also might offer guidance for setting up a program or better conducting an operation, or a service. Monographs, as well as the literature as a whole, identify who is working on something; librarians thereby identify contacts. Participants in one focus group interview explained that they use the literature to identify the "big shots" and see what these people are doing. Because such individuals effect change, their writings are important. The next section 
of the paper identifies another use of monographs-research and publication.

\section{Promotion and Tenure Requirements}

Those interviewed realize that library school educators and some academic librarians facing promotion and tenure requirements may be unwilling to write practical guides or monographs. These individuals might have to produce works that are philosophical, theoretical, and research based. The librarians interviewed, however, would probably not purchase such works.

\section{The librarians interviewed want how-to-do-it manuals, summaries of the published literature, and statistics and research methods books.}

Expectations that the librarians would engage in publication provide an incentive for them to consult the monographic literature. However, conversations with some librarians indicated a cavalier attitude toward the conduct of a literature review. Two librarians interviewed had just submitted a proposal to a funding organization. They had conducted no literature review, nor were they aware of the key writings on the topic. They intended to leave the search for relevant literature until after the proposal had been funded. The search would constitute the first phase of the project. Unfortunately, the existing literature already covers the proposed project in some depth.

\section{Interlibrary Loan}

The prevailing attitude of many of the librarians is that "something important and potentially useful may fall through the cracks and not be purchased. This is only natural." When the staff need a monograph, or a portion of one, they can check OCLC or a similar networking utility to see which libraries own it; then they borrow the title through interlibrary loan. The librarians interviewed tend to identify the source of interlibrary borrowing of LIS monographs as academic institutions having graduate schools of LIS. They assume that these schools, especially the ones with doctoral programs, maintain comprehensive research-level collections and would lend monographs, or photocopy or fax a chapter or selected pages. However, they have neither verified the accuracy of this assumption nor attempted to borrow a work.

\section{TOPICS MERITING INVESTIGATION}

The pressure for librarians to perform research and publish depends on variables such as an institution's promotion and tenure requirements, the librarians' faculty status, and the library's size. ${ }^{33}$ Faculty status requiring research and publication might be the catalyst for more academic librarians to consult the literature, especially monographs that are not how-to-do-it manuals. Therefore, studies might expand on this investigation and examine in-depth faculty status at other doctoral-granting institutions. What types of literature do these librarians consult, produce, and cite?

Research might explore the importance of publishing a monograph as a precondition to obtaining promotion and tenure. $W$. Bede Mitchell and L. Stanislava Swieszkowski examined publication requirements and tenure approval rates. As part of their study, they probed whether or not responding institutions gave librarians credit for different types of publications. ${ }^{34}$ Their research merits replication; the new research should test the comparative weight accorded a publication type. ${ }^{35}$ The findings of such research might be included as part of a model depicting fully the variables on which institutions make promotion and tenure decisions. ${ }^{36}$

The study reported in this paper might be replicated among faculty and doctoral students in graduate schools of LIS. Replication also might extend to librarians affiliated with public and other types of libraries, including academic institutions offering degrees other than the doctorate.

Given the importance of recognized library leaders and their writings, future research might build on Alice Gertzog's 
identification of leaders. ${ }^{37}$ Instead of merely listing leaders by library type, it might be beneficial to categorize them in the context of particular issues, problems, and areas of librarian responsibility-for example, reference service. In addition, there should be an attempt to identify the more important writings of these leaders.

\section{Conversations with some librarians indicated a cavalier attitude toward the conduct of a literature review.}

Research might explore the perceptions of publishers and use content analysis to examine patterns among the monographs mentioned in publishers' catalogs. Finally, research might probe, in greater depth, perceptions about topics inadequately covered in the monographic literature and the relationship of LIS literature to the broader social sciences literature.

\section{CONCLUSION}

On the one hand, some publishers, academic librarians, and university promotion and tenure committees do not attach much importance to monographs. Some publishers have acknowledged a declining sales potential for the LIS monograph and have characterized this type of monograph as a dead or dying commodity as far as their publishing houses are concerned. ${ }^{38}$ On the other hand, other publishers, including G. K. Hall \& Co., have issued a call for authors. ${ }^{39}$

Those interviewed tend to prefer a monograph that synthesizes existing literature or is a how-to-do-it manual. Neal-Schuman produces such manuals as part of a series edited by Bill Katz, a professor at the State University of New York-Albany School of LIS and Policy. The librarians interviewed also encourage fellow practitioners and faculty at graduate schools of LIS to prepare such manuals. However, they realize that these manuals may not factor into promotion and tenure decisions. At some universities, publication in the form of monographs does not seem to count for nearly as much as the placement of research articles in refereed journals. ${ }^{40}$ However, this may be more true for LIS faculty than for library faculty. Publishers and series editors wanting research-based monographs may have to implement a formal peer reviewing system in order to generate a more positive perception of monographs among some promotion and tenure committees. ${ }^{41}$

When libraries commit an increasing percentage of the materials budget to the periodicals collection and the use of technology, other collections, such as the monograph collection, may be penalized. According to one librarian interviewed, "It is easier to cancel monographs than to evaluate and get rid of serials. We focus more attention on serials and offer departments an incentive to cancel serials: we'll replace some with new orders." From discussions with academic librarians, it would seem that they value the periodical and monograph literature of other disciplines and professions more than LIS literature. ${ }^{42}$ Charges that LIS monographs vary substantially in quality and rarely contain anything new may have some merit. On the other hand, these charges may provide a rationale for neglecting the purchase of LIS monographs, conference proceedings, and other publication types.

Charles R. McClure studied information source preferences among academic library decision makers. ${ }^{43}$ The librarians interviewed for this article displayed similar preferences. For decision making, they prefer the use of interpersonal sources, including electronic mail; with e-mail they can put out questions and obtain immediate information useful for decision making and problem resolution. When they consult the professional literature, it is most likely that which is easily accessible - office copies of monographs and journals to which the library subscribes.

Faculty status and expectations that librarians will engage in publication underscore the fact that librarians preparing reviews of the literature must include the major writings, be they jour- 
nal articles, monographs, or so forth. The search for monographs synthesizing the published literature may be limited to the holdings of the immediate collection. The presumption is that the library indeed holds the significant works. An interesting, but perhaps not researchable, question is: "Do librarians submitting manuscripts for publication include the major works in their literature reviews, or must the editorial boards of refereed journals point out key omissions for potential authors to include as they revise their papers?"

Looking toward the future, the LIS monograph will evolve in response primarily to market demands-the purchase preferences of libraries and the dissatisfaction of authors with book sales that do not match their expectations. When monographs report original research, perhaps they should not merely relate the reflective inquiry (problem statement, literature review, theoretical framework, logical structure, objectives, hypotheses, and research questions), procedures (design and methodology), indicators of reliability and validity, limitations, and findings. Greater attention might focus on the packaging, readability, and generalizability of the research. ${ }^{44}$ Yet popularizing research may have an adverse effect on promotion and tenure committees that expect research to conform to the scientific method and technical report writing. ${ }^{45}$

In summary, the librarians interviewed accord high priority to the purchase of titles for academic departments and low priority to the collection of LIS monographs. When they do acquire their own literature, it is most likely in the form of a serial. Nonetheless, they claim satisfaction with their libraries' roles in acquiring LIS titles that support their professional needs. ${ }^{46}$

Regardless of the changes that the monograph may undergo, it will remain a secondary means for the dissemination of research and other information to the library community. ${ }^{47}$ The journal article is indeed the primary vehicle for conveying published information. Publication of electronic journals will ensure this preeminence because librarians will gain access to more timely information.

\section{REFERENCES AND NOTES}

1. Charles B. Osburn, "The Place of the Journal in the Scholarly Communications System," Library Resources \& Technical Services 28:323-24 (Oct. 1984).

2. In one study, ARL directors listed the following journals as the most significant for promotion and tenure in the following order: College \& Research Libraries, Library Quarterly, Journal of Academic Librarianship, Library Resources \& Technical Services, Library Trends, Information Technology and Libraries, Journal of the American Society for Information Science, Library Journal, American Libraries, and RQ. See David F. Kohl and Charles H. Davis, "Ratings of Journals by ARL Library Directors and Deans of LISSchools," College \& Research Libraries 46:40-47 (Jan. 1985).

3. See, for example, Carolyn O. Frost, "The Literature of Online Public Access Catalogs, 1980-85: An Analysis of Citation Patterns," Library Resources \& Technical Services 33:345 (Oct. 1989); Stephen Atkins, "Subject Trends in LIS Research, 1975-1984," Library Trends 36:635 (Spring 1988); Kohl and Davis, "Ratings of Journals by ARL Library Directors and Deans of LIS Schools," p.43; S. Nazim Ali, "LIS Literature: Research Results," International Library Review 17:120 (April 1985); S. Nazim Ali, "Library Science Research: Some Results of Its Dissemination and Utilization," Libri 35:160-61 (June 1985); S. Nazim Ali, "Attitudes and Preferences of Library Practitioners in Illinois to Channels for Dissemination of Research Results," College \& Research Libraries 47:167 (Mar. 1986); and Peter Lynam, Margaret Slater, and Rennie Walker, Research and the Practitioner (London: Aslib, 1982), p.8.

4. Diane Mittermeyer and Lloyd J. Houser, "The Knowledge Base for the Administration of Libraries," Library Research 1:255-76 (Fall 1979); and Lloyd J. Houser and Wilma Sweaney, "Library Administration Literature: A Bibliometric Measure of Subject Dispersion," Library Research 1:359-75 (Winter 1979). 
5. This is not to say that use of LIS journal literature is minimal. See Atkins, "Subject Trends in LIS Research"; and Dale S. Montanelli and Collette Mak, "Library Practitioners' Use of Library Literature," Library Trends 36:765-83 (Spring 1988).

6. Mittermeyer and Houser, "The Knowledge Base for the Administration of Libraries," p. 273.

7. Sharon J. Rogers and Charlene S. Hurt, "How Scholarly Communication Should Work in the 21st Century," College \& Research Libraries 51:5-6, 8 (Jan. 1990).

8. Calvin J. Boyer, The Doctoral Dissertation as an Information Source (Metuchen, N.J.: Scarecrow, 1973).

9. Beverly P. Lynch, "Research, Theory, and the Practice of LIS," in LIS Research: Perspectives and Strategies for Improvement, eds. Charles R. McClure and Peter Hernon (Norwood, N.J.: Ablex, 1991), p.360.

10. Sandra R. Moline, "The Influence of Subject, Publisher Type, and Quantity Published on Journal Prices," Journal of Academic Librarianship 15:12 (March 1989). See also Bernard M. Fry and Herbert S. White, Publishers and Libraries: A Study of Scholarly and Research Journals (Lexington, Mass.: Lexington Books, 1976).

11. Robin B. Devin and Martha Kellogg, "The Serial/Monograph Ratio in Research Libraries: Budgeting in Light of Citation Studies," College \& Research Libraries 51:46-54 (Jan. 1990).

12. Volume 5 of LIS Annual (Englewood, Colo.: Libraries Unlimited, 1989), p.ix, includes more than 500 monographs, reference books, and periodicals for the United States, Canada, Great Britain, Australia, and India. The 500 represents a crude overestimation of the number of published monographs, assuming that the Annual provided comprehensive coverage.

13. In regard to university presses, "very few have print orders over 1,000 , many have less than 1,000 and estimates of typical sales run variously from 400 to 750 copies." See Chandler B. Grannis, "New Directions for University Presses," Library Journal 11:74 (Aug. 1986).

14. Using data for only one year (September 1986 through August 1987), Paul Kobasa examined 300 titles available from the American Library Assn. He found that only thirty of these sold at least 1,000 copies. He categorized the thirty works as "reference" (eleven titles), "philosophical/theoretical" (two titles), and "practice/procedural" (seventeen titles). (His study definitely merits replication over a longer time period.) See Paul A. Kobasa, "Synergy, Not Cause and Effect: The Library Profession and Its Literature," Library Trends 36:695-708 (Spring 1988).

15. Lecture by Klaus G. Saur at Simmons College, July 12, 1990.

16. It is interesting to note that a newly established library school in Sierra Leone has asked libraries serving North American graduate schools of LIS for donations of books and journals.

17. The two publishers supplying this information as well as sharing the size of the print runs for many publishing houses requested that their names be withheld.

18. Research might probe the motivation for publication and the preparation of monographs. "In answer to the obvious question, Why continue to produce titles in a category that does not sell well, it can be said that a professional association publisher [the American Library Assn.] has a service motive in addition to that of profit.... There may be a sense that philosophical/theoretical works-'serious' works, scholarly works-somehow legitimize a publishing program overall in the eyes of library professionals. These items position the publisher as a significant source of professional information. In other words, there is a value to pursue beyond that of numbers of copies sold-i.e., a wish to contribute to theory development in the profession in order to compete effectively for the attention of the profession in the marketplace of more lucrative products." See Kobasa, "Synergy, Not Cause and Effect," p.701.

19. Examples of these publishers include Ablex Publishing Corp., the American Library Assn., G. K. Hall \& Co., Greenwood Press, Libraries Unlimited, Meckler Corp., NealSchuman, Oryx Press, Saur, and Scarecrow Press. The study excludes Haworth Press and its reprinting of journal issues as monographs. 
20. For a discussion of focus groups see David L. Morgan, Focus Groups as Qualitative Research (Newbury Park, Calif.: Sage, 1988); Richard A. Krueger, Focus Groups (Newbury Park, Calif.: Sage, 1988); and David W. Stewart and Prem N. Shamdasani, Focus Groups: Theory and Practice (Newbury Park, Calif.: Sage, 1990).

21. See, for example, Michael Q. Patton, Qualitative Evaluation and Research Methods (Newbury Park, Calif.: Sage, 1990); Matthew B. Miles and A. Michael Huberman, Qualitative Data Analysis (Beverly Hills, Calif.: Sage, 1984); Robert C. Bogdan and Sari K. Biklen, Qualitative Research for Education (Boston: Allyn \& Bacon, 1982); and C. A. Mellon, Naturalistic Inquiry for Library Science (New York: Greenwood, 1990).

22. See Robert K. Yin, Case Study Research (Newbury Park, Calif.: Sage, 1989).

23. Donald Ary, Lucy Cheser Jacobs, and Asghar Razavieh, Introduction to Research in Education, 3d ed. (New York: Holt, 1985), p.323.

24. Patricia S. Breivik and E. Gordon Gee, Information Literacy (New York: American Council on Education/Macmillan, 1989); F. W. Lancaster, If You Want to Evaluate Your Library (Champaign: Univ. of Illinois, Graduate School of LIS, 1988); and Nancy A. Van House, Beth T. Weil, and Charles R. McClure, Measuring Academic Library Performance (Chicago: American Library Assn., 1990).

25. Beverly P. Lynch, University of California, Los Angeles, before the Library Research Round Table, American Library Association, June 23, 1990.

26. Nancy A. Van House, University of California, Berkeley, before the Library Research Round Table, American Library Association, June 23, 1990. S. Nazim Ali, however, would substitute "scholarly and middle-of-the-road" for "widely circulating." See Ali, "Library Science Research," p.160-61.

27. The assumption is that all titles ordered for academic disciplines are indeed used. See Allen Kent, Jacob Cohen, K. L. Montgomery, James A. Williams, Stephen Bulich, Roger P. Flynn, William N. Sabor, and Una Mansfield, Use of Library Materials (New York: Dekker, 1979).

28. Charles R. McClure and Ann Bishop, "The Status of Research in Library/Information Science: Guarded Optimism," College \& Research Libraries 50:127-43 (Mar. 1989).

29. One librarian believes that "we could cut the number of LIS journals and monographs in half, with no significant loss of information."

30. The collection management guidelines at one library emphasize that the budget for a department will have a proportion of serials and monographs. (This does not apply to the LIS collection.) A department may expend more than that allotted for its serials holdings. The library also needs technology and takes the funds from whatever budget it can. If the librarians see something that is important, such as a CD-ROM service, they may pick it up on a trial basis and charge the expenditure to the monograph budget. If they decide to continue with the service, they shift funding to another budget.

31. For supporting evidence that librarians rate as most important research having practical application, see notes 3 and 5 . Several of those interviewed believe that library educators "look down on practice" and treat theory at the expense of practice. For these practitioners to purchase monographs written by library educators, the works would have to emphasize practice and be useful in their everyday work.

32. After examining ALA sales records for one year, Kobasa concluded that "approximately 90 percent of ... [ALA's best-sellers] cost less than $\$ 30 ; 75$ percent cost less than \$20." See Kobasa, "Synergy, Not Cause and Effect," p.702.

33. See Sylvia C. Krausse and Janice F. Sieburth, "Patterns of Authorship in Library Journals by Academic Librarians," The Serials Librarian 9:132 (Spring 1985).

34. W. Bede Mitchell and L. Stanislava Swieszkowski, "Publication Requirements and Tenure Approval Rates: An Issue for Academic Librarians," College \& Research Libraries 46:249-55 (May 1985).

35. It also might be useful to replicate Karen F. Smith, Tamara V. Frost, Amy Lyons, and Mary Reichel, "Tenured Librarians in Large University Libraries," College \& Research Libraries 45:91-98 (Mar. 1984).

36. Development of such a model becomes more important as some of the major research universities contemplate fundamental change, including the formulation of a new paradigm to guide higher education in the future. See Karen Grassmuck, "Some 
Research Universities Contemplate Sweeping Changes, Ranging from Management and Tenure to Teaching Methods," The Chronicle of Higher Education 37:A1, A29-A31 (Sept. 12, 1990).

37. Alice Gertzog, "Library Leaders: Who and Why?" Library Journal 115:45-51 (July 1990).

38. See note 17.

39. G. K. Hall \& Co. issued a call for authors of scholarly monographs, handbooks, textbooks, management guides, and collections of essays. Its interests include, but are not limited to, the following areas: library automation and technology, library management and administration, fundamentals of librarianship, information policy and strategy, information science, school media librarianship, comparative and international librarianship, communications, and information management." Letter from Carol C. Chin, Senior Editor, G. K. Hall \& Co., to professors at graduate schools of LIS, April 1990.

40. In contrast to this finding, Joyce Payne and Janet Wagner discovered "that the form of publication was less significant [for promotion and tenure requirements] than the fact of publication." This study, published in 1984, merits replication. See Joyce Payne and Janet Wagner, "Librarians, Publication, and Tenure," College \& Research Libraries 45:138 (Mar. 1984). One librarian questioned the generalizability of this finding. He believes that "this may vary between institutions, between an institution's school of LIS and its department of library services, and with type of monograph-research versus reprinted essays, etcetera."

41. Social judgment analysis might provide a useful framework for the conduct of such an investigation. See Ann McCartt, "The Application of Social Judgment Analysis to Library Faculty Tenure Decisions," College \& Research Libraries 44:345-57 (Sept. 1983).

42. One librarian suggested that the prizing of literatures other than LIS may reflect "ignorance of the shortfalls of other disciplines' literature. We are aware of the shortfalls of our own literature."

43. Charles R. McClure, Information for Academic Library Decision Making (Westport, Conn.: Greenwood, 1980).

44. One librarian suggested that the body of a research-based monograph might contain an introduction to the topic, a summary of the findings, and a discussion of the "importance of findings to day-to-day library operations." An appendix could contain a detailed presentation of findings, the study design, and methodology. Placement of these items in the appendix means that "not everyone needs to read them."

45. Some librarians may attempt to get two versions of a study published-one for a popular periodical and the other for a scholarly journal.

46. S. Nazim Ali found a similar degree of satisfaction among his respondents. See Ali, "Attitudes and Preferences of Library Practitioners," p.168.

47. Publishing houses, such as Pantheon Books, are shifting "away from medium-selling books toward more popular titles." Clearly, the types of problems discussed in this paper transcend LIS and have a profound impact on the social sciences and humanities. See Sanford Thatcher, "Scholarly Monographs May Be the Ultimate Victims of the Upheavals in Trade Publishing," The Chronicle of Higher Education 37:B3 (Oct. 10, 1990). 


\section{When it comes to academic inventory, \\ these cats cover every subject.}
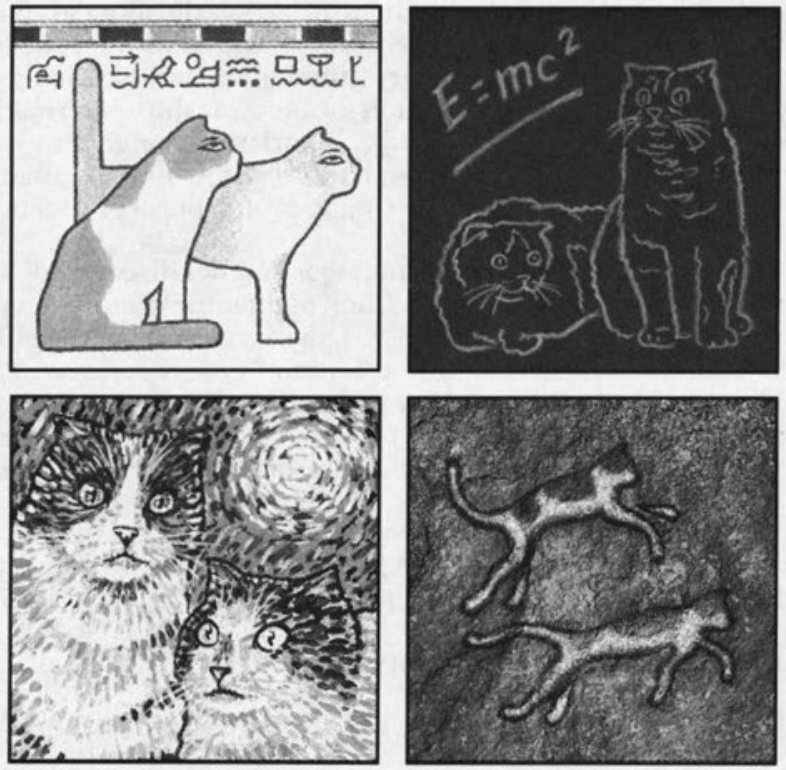

\section{You can count on Baker \& Taylor Books for a first fill rate that's second to none.}

It's not surprising. With 400,000 academic books in our inventory, Baker \& Taylor Books delivers a first fill rate that's twice that of any other academic vendor.

Over $35 \%$ of all academic books on order are shipped within five working days. And over $90 \%$ of titles are shipped or reported within 90 days.

You can count on specialized titles from scholarly, research and scientific publishers, societal and association presses, university and small presses.

And, you can expect more than just current titles.
We inventory more than 167,000 academic books printed before 1988 .

You'll even have the benefit of the most sophisticated electronic search and purchase system on the market today - B\&T Link ${ }^{\mathrm{TM}}$. It offers unprecedented accuracy with a 1.2 million title database on CD-ROM, and the fastest, easiest ordering system around.

When it comes to meeting your most demanding academic book needs, Baker \& Taylor Books is in a class by itself. For more information, call Baker \& Taylor Books. 